\title{
Body metamorphosis in dystopian cyber-capital of Don Delillos Cosmopolis
}

\begin{abstract}
This study examines the metamorphosis of the body in cyberspace. From the late twentieth century to the early twentieth-first century, we have witnessed a remarkable development of new technologies that have affected our concept of being. The body has been metamorphosed into pattern and has lost its possession in order to gain immortality. Its function or meaning no longer depends on an interior truth or identity, but on the particular assemblages it forms with new technologies. In this study, we draw on the work of Hayles, Haraway, Deleuze and Guattari among some other scholars to explore what happens to the body when it is rethought as pattern in Don DeLillo's Cosmopolis (2003). In the present study, we argue on a departure from capital to cyber-capital with the idea of futurity. We also demonstrate the construction of a megalomaniac in the virtual realm and that how technology and cyber-capital have affected the human body.
\end{abstract}

Keyword: Pattern; Access; Paranoid schizophrenia; Megalomania; Dystopia; Cybercapitalist 